\title{
Entrepreneurial Intention: A Gender Study in Business and Economics Students from Chile
}

\author{
Nicolás Contreras-Barraza ${ }^{1}$, Juan Felipe Espinosa-Cristia ${ }^{1}\left(\mathbb{D}\right.$, Guido Salazar-Sepulveda $^{2}(\mathbb{D})$ \\ and Alejandro Vega-Muñoz ${ }^{3, * \text { (D) }}$ \\ 1 Facultad de Economía y Negocios, Universidad Andres Bello, 2531015 Viña del Mar, Chile; \\ nicolas.contreras@unab.cl (N.C.-B.); juan.espinosa@unab.cl (J.F.E.-C.) \\ 2 Departamento de Ingeniería Industrial-Facultad de Ingeniería, Universidad Católica de la Santísima \\ Concepción, 4090541 Concepción, Chile; gsalazar@ucsc.cl \\ 3 Public Policy Observatory, Universidad Autónoma de Chile, 7500912 Santiago, Chile \\ * Correspondence: alejandro.vega@uautonoma.cl
}

Citation: Contreras-Barraza, N.; Espinosa-Cristia, J.F.; Salazar-Sepulveda, G.; Vega-Muñoz, A. Entrepreneurial Intention: A Gender Study in Business and Economics Students from Chile. Sustainability 2021, 13, 4693. https://doi.org/10.3390/su13094693

Academic Editors: Bing Ran and Marc A. Rosen

Received: 31 March 2021

Accepted: 20 April 2021

Published: 22 April 2021

Publisher's Note: MDPI stays neutral with regard to jurisdictional claims in published maps and institutional affiliations.

Copyright: (c) 2021 by the authors. Licensee MDPI, Basel, Switzerland. This article is an open access article distributed under the terms and conditions of the Creative Commons Attribution (CC BY) license (https:/ / creativecommons.org/licenses/by/ $4.0 /)$.

\begin{abstract}
The study of entrepreneurial intention sheds new light on the complex dynamics of entrepreneurial behavior. This research contributes to the academic debate by examining the gap in studies on entrepreneurial intention in Latin America, considering the importance of gender differences and their effects on entrepreneurial intention. Thus, this study is a contribution to research on the Sustainable Development Goals (SDGs) related to social equity, in the areas of quality education (SDG 4), gender equality (SDG 5), and inequalities reduction (SDG 10). To study gender entrepreneurial intention phenomena differences, researchers have taken refuge in the Theory of Planned Behavior (TPB) and focused their analysis on a group of economics and business students from a coastal campus of a Chilean University. In a two-step methodological process, the authors verified the applicability of the entrepreneurial intention questionnaire (CIE) with the selected sample and then calculated entrepreneurial intention using the CIE instrument. Contrary to general literature results, the study shows that there are no significant gender differences in entrepreneurial intention levels. Furthermore, there is neither evidence for gender differences in any of the three entrepreneurial intention factors, i.e., (a) attitudes, (b) subjective norms, and (c) control of perceived behavior.
\end{abstract}

Keywords: entrepreneurial intention; theory of planned behavior; gender; entrepreneurship; blue economy; quality education; gender equality

\section{Introduction}

Recent research on entrepreneurship education underscores the need for a better understanding of the complexity and dynamics of the entrepreneurial learning process. This research stream maintains that, in addition to understanding cognitive processes, the interaction between affective and conative constructs is essential to analyze entrepreneurial behavior [1-5]. The entrepreneurship phenomenon and the interest to know more about entrepreneurial characteristics have led researchers around the world to increase scientific production that tries to understand the factors and different dimensions of entrepreneurship [6,7] Among them, a fertile line of studies related to entrepreneurial intention. Literature defines entrepreneurial intention (EI) as the identification of the conviction to create a business and conscious planning for its realization in a future time [8].

Starting a business requires individuals to do planned work. Besides the individual's value system, their culture, social, family, and educational environment can shape the desire to create or not create their own company [8]. However, given that the creation of companies involves the planning of behavior on the part of the individual, the literature has shown that the behavioral intention models; considering aspects about culture, social, educational, and family environment; are robust in this field of research on entrepreneurial intention [9]. In particular, the Theory of Planned Behavior (TPB) [10,11], had been widely 
used in various areas to predict different types of behavioral intentions [12-16]. As many authors claim, TPB constitutes the most widely used model in the study of EI in different countries [17-21].

EI literature had been systematically measuring how individuals' self-efficacy, subjective norm, and attitude explain entrepreneurial behavior. The present study inquiry is about one EI dimension related to EI, which is gender. There is countless research that has indicated the interest in studying the effect of gender on the entrepreneur intention [22-26]. Literature shows controversial results about the differences between male and female EI measures. The issue of gender EI differences had been tested for a variety of groups and individuals. Some studies indicate that there are gender differences in the propensity towards entrepreneurial activity and business initiatives [27,28]. For example, Tsui [29] demonstrates that women perceive a higher degree of fear of failure and a lower degree of self-efficacy than males in the USA and Belgium. Other studies, such as Wilson, Kickul, and Marlino [30] find gender effects on entrepreneurial self-efficacy examining in two sample groups of adolescents and adult Master of Business Administration (MBA) students [30], explain that the females present a higher level of self-efficacy that leads to a higher degree of EI.

Further, literature on entrepreneurship considers that university students conform to a community with high entrepreneurial potential [31]. Additionally, student samples are a good way to represent aspects of society's potential entrepreneurial activities [32]. Considering differences in gender EI and the university student entrepreneurial potential, this study revisits the controversy about the effect that gender has on IE, measuring the result in the university community. Accordingly, this study seeks to answer the possible gender differences in entrepreneurial intention in a population of administration and economics students in Chile.

The study presents a case about a university coastal campus. This city, Viña del Mar, is well known for its level of tourism and entrepreneurship related to leisure in the summer seasons. Researchers applied an instrument developed by Rueda, Moriano, and Liñán [33]. This instrument measures IE using an entrepreneurial intention questionnaire (CIE). The sample surveyed corresponds to 435 economics and administration students in the city of Viña del Mar, belonging to a population of 867 , with a response rate for the applied instrument of $50.17 \%$ undergraduate students of that study program at the headquarters of Andres Bello National University (UNAB). This university is a secular and private institution created in 1988 and which is characterized by admitting students of all creeds and diverse disciplines. The university has been classified as a massive university, oriented to undergraduate training, whose students come mainly from emerging social sectors [34-36]. It is important to mention that the administration and economics program has a national femininity index distributed by $45 \%$ of women and $55 \%$ of men $[37,38]$.

Results show that there are no significant gender differences in entrepreneurial intention levels. Furthermore, there is no evidence for gender differences within any of three entrepreneurial intention factors, i.e., (a) attitudes, (b) subjective norms, and (c) control of perceived behavior.

\section{Entrepreneurial Intention and Gender}

\subsection{Entrepreneurial Intention}

The importance of IE lies in the fact that it is considered a prerequisite to entrepreneurial action [39]. The first model of entrepreneurial intentions within the framework of the entrepreneurship literature was the Entrepreneurial Event Model (EEM). Shapero and Sokol [40] proposed that there are a group of factors that need to be studied together with individual entrepreneur traits to understand the whole complexity of any intentional behavior. In their model, these authors propose that the desirability and feasibility with which an individual perceives the entrepreneurial event will impact their decision to start up. The model presents high importance to the desirability and feasibility of entrepreneurial action. If one perceives that the creation of a company is unfeasible, one can conclude that it is 
undesirable. In the same vein, by intuiting that it is undesirable, anyone may never come to consider it as a viable possibility. According to the authors, family, peer, educational, and professional contexts conditions desirability.

Some years later, Ajzen [10] proposed the Theory of Planned Behavior (TPB). Since the TPB entrepreneurship, scholars have been using TPB widely and extensively [10]. According to the TPB, there are three elements: attitude towards behavior, subjective norms, and perception of control of behavior that shapes the intention. Both the EEM and the TPB have been empirically tested on numerous occasions and show significant power of prediction for entrepreneurial behavior [18]. TPB's foundational idea is that humans plan their behavior, and such human behavior is preceded by individual intentions. Consequently, the intention is an accurate predictor of planned behavior [10].

Krueger and Carsrud [41] were pioneers in applying Azjen's TPB in the field of entrepreneurship, which postulates that education and training can influence the perception and intentions of students towards entrepreneurship [10]. According to Krueger et al. [18], any individual entrepreneurial activity can be more accurately predicted by studying entrepreneurial intention (EI), rather than personality traits, demographic characteristics, or situational factors of entrepreneurs. EI is a psychological construction that precedes a behavior given at the individual level. The central factor in Azjen's [10] model explains the level of intention that an individual presents to become an entrepreneur. The TPB holds that intentions are a function of three sets of factors: (a) attitudes, (b) subjective norms, and (c) control of perceived behavior. The attitude towards the behavior is a personal factor. Such attitude concerns the favorable or adverse evolution of the individual in the performance of the behavior. It refers to a person's judgment as to whether performing a particular behavior is good or bad, or whether one is for or against it. Subjective norms or perceived social norms are individual's perceptions about values, beliefs, and norms that people have whom they respect or consider essential, and the desire of individuals to comply with those norms [10,11]. Additionally, control over perceived behavior is the perception of the ability to perform some behavior. Control over perceived behavior also refers to the resources or opportunities available to a person, which, to some degree, should dictate the probability of achievement in the behavior.

Veciana [42] recognizes those different elements of the context that impact intention model variables. Expanding on the model of Krueger and Brazeal [43], Veciana [42] considers that environmental variables impact the individuals' attitudes, and at the same time, play a moderating role in the influence of the potential intention of individuals that decide to create a company. The author concludes that such factors could be personal motivations, such as the desire for independence and personal fulfillment. Furthermore, some trigger events, already proposed by Shapero and Sokol [40], such as a dismissal or lack of promotion within a company can be environmental variables that influence intentions to create companies.

\subsection{Entrepreneurial Intention and Entrepreneur Education}

Entrepreneurship education (EE) is gaining recognition as a form of formal teaching within business and management studies [44]. In addition, there is a high interest in investigating its characteristics and nature $[45,46]$. While some studies indicate that EE is still in an initial stage as a field of research [47], others show a great interest in the research community to deepen its knowledge [45]. The main reason for considering $\mathrm{EE}$ as an incipient field of research is the significant heterogeneity of the definitions of entrepreneurship within the field of pedagogical sciences, without detracting from the relevance and importance of its study $[7,45,46]$.

Furthermore, EE presents various curricular contents and different pedagogical ways of teaching entrepreneurship in university programs and courses [48,49]. Such heterogeneity in ways of teaching and the uses of different conceptualizations puts a challenge for research activity [44]. 
Additionally, EE is continuously evolving [50] and trying to generate knowledge about which are the best practices or the most effective teaching approaches for learning entrepreneurial skills. All in all, there is some consensus about the need for a rigorous and robust EE research program [51]. Relationships between educators, their beliefs, their students, and pedagogical actions used need further investigation [5,52]. Some argue that understanding EE philosophies, rather than focusing exclusively on pedagogical approaches appears to be highly relevant if one is looking for impact in the field [53]. In the same way, teaching intentions and actions are the results of the underlying beliefs that this group has about the philosophical paradigms about education [54], and the relevant theories of the disciplines they teach [55]. Consequently, the form in which researchers define entrepreneurship affects what educators teach in entrepreneurship workshops and courses $[44,56]$.

Finally, the authors suggest that some educational variables in EE, such as pedagogical methods, teaching approaches, and the type of learning outcomes, can affect entrepreneurial intention [52]. In this vein, a research group in a German university tries to measure whether compulsory entrepreneurship courses affect entrepreneurial intention. Then, researchers used the responses of the ex-ante and ex-post surveys of the students using a questionnaire, finding that these courses positively and significantly affected their entrepreneurial intention [57]. Additionally, Krueger and Carsrud [41] and Fayolle and Liñan [58] highlighted that the TPB could be used to analyze how the different types of pedagogies (active and passive methodologies) in EE classes affect the level of business student intentions. Specifically, educational variables such as pedagogies and learning objectives in EE deserve more research on the effects of entrepreneurial intention and its antecedents on the student level [44].

\subsection{Gender}

The research focused on women entrepreneurs and their entrepreneurial development has increased in recent years as it is considered a potential source of sustainable development in economic and social matters [59]. There is a high stream of research that has indicated an interest in studying the effect of gender on EI [22-26]. Gender is a fundamental dimension of the sociocultural environment and can therefore be a possible determinant of EI and entrepreneurship more broadly. Despite the increase in the number of women entrepreneurs [60,61], some studies indicate that females present a lower propensity towards entrepreneurial activity and the start-up of new companies $[27,28]$. Some studies directly associate entrepreneurial intention with masculine traits $[23,62,63]$. Furthermore, some authors claim that female entrepreneurial intention is significantly lower than male entrepreneurship intention [64].

Reasons for the gender business and entrepreneurship gap are still not clearly understood [65]. A critical factor in such a gap could be individual perceptions, propensities, and entrepreneurial intentions [66]. Therefore, studying gender differences in entrepreneurial intentions and behavior could help researchers and policymakers to foresee reasons for that kind of lower entrepreneurship activities [67]. There may be discrepancies in different types of academic programs, whether business or not [68-70]. However, most of the research about entrepreneurial intention and entrepreneurship presents a bias because it is based on cases in developed western countries, such as the US and the UK [71]. Likewise, a female stereotype that is far removed from the entrepreneurial spirit can be a major barrier to planning a venture in a developing country [72], and research that the training of female university students is very important for their entrepreneurial spirit [73]. Stereotypes and social perceptions of gender in each culture may not consider female entrepreneurship appropriate, this may cause female entrepreneurship to be less profitable, smaller, and less growth-oriented than those managed by men, as could be seen in the case of Chile and the United Arab Emirates [74-78].

Thus, according to the considerations previously presented by Gupta et al. [23], Wilson et al. [30], Rueda et al. [33], Krueger et al. [43], Norton et al. [54], Fayolle et al. [58], Sahinidis 
et al. [68], Ferri et al. [70], and Díaz-García et al. [77], it is possible for us to formulate the following hypothesis:

Hypotheses 1(H1). There is no significant difference between male and female students of economics and management schools in the Entrepreneurial Intention.

On the other hand, as indicated by Krueger et al. [41], Ajzen [11], Wilson et al. [30], Rueda et al. [33], Gupta et al. [23], Norton et al. [54], Sahinidis et al. [68], Ferri et al. [70], and Yordanova et al. [78] allows us to formulate It allows us to formulate the hypothesis:

Hypotheses 2(H2). There is no significant difference between male and female students of economics and administration schools in the Self-Efficacy.

In turn, what is pointed out by the authors Krueger et al. [41], Ajzen [11], Wilson et al. [30], Rueda et al. [33], Gupta et al. [23], Norton et al. [54], Sahinidis et al. [68], Ferri et al. [70] and Pincay et al. [79] make it possible to formulate the hypothesis:

Hypotheses 3(H3). There is no significant difference between male and female students at the schools of economics and administration in the Attitude towards Entrepreneurship.

Finally, what is pointed out by Krueger et al. [41], Ajzen [11], Wilson et al. [30], Rueda et al. [33], Gupta et al. [23], Norton et al. [54], Sahinidis et al. [68], Ferri et al. [70] and Tarapuez et al. [80] allow us to formulate the following hypothesis:

Hypotheses 4(H4). There is no significant difference between male and female students of economics and management schools in the Subjective Norm.

\section{Methodology}

Authors use the entrepreneurial intention questionnaire (CIE) to measure EI. Rueda, Moriano and Liñán [33] developed this EI measurement instrument [81] and validated their questionnaire for the Latin American context. Similarly, Laguía et al. [81] commented that CIE is widely used in various LA IE contemporary studies [82-89] (The complete questionnaire is in Appendix ??). The authors applied the survey to 435 economic and business students in the city of Viña del Mar. Those students belong to a population of 867 undergraduate students from Andres Bello University located at Viña del Mar city.

The authors used SPSS 23 (IBM, New York, NY, USA) to analyze the 15-item CIE questionnaire. To measure confidence levels, the authors applied the Kaiser-Meyer-Olkin measure of sampling adequacy (KMO). Moreover, the authors used Bartlett's test of sphericity to identify items belonging to the three (3) factors within the scale as a form of exploratory factor analysis (EFA) with extraction method, unweighted least squares (ULS), and rotation method, Oblimin with Kaiser normalization [90]. Then the authors analyzed the CIE factors utilizing a confirmatory factor analysis (CFA) with FACTOR software (see Appendix C) [91]. The authors used the Hull method for selecting the number of common factors [92], considering a dispersion matrix with polychoric correlations. Such polychoric correlations are a method for factor extraction unweighted least squares (ULS) and a rotation to achieve Normalized Direct Oblimin simplicity factor [93,94]. Before the measurement of normalized direct Oblimin simplicity factor, the authors calculated KMO and Bartlett's test on the resulting factors $[95,96]$. The expected mean value of RMSR (root mean square residual) is equal to 0.0481 under Kelley's criterion, it is acceptable for the model [96] (p. 146). Results were weighted by the set of eigenvalues, accounting for the entrepreneurial intention of the group of students analyzed [97] (p. 44). Authors compared each factor by gender differences.

Researchers produced a data set through the CIE survey and then analyzed it with cross tables, given the high presence of ordinal or categorical variables. Researchers used a non-parametric correlation coefficient tau-b $(\tau b)$ of Kendall. Researchers use $\tau b$ to measure the strength and direction with which two variables of these characteristics are associated. That is to measure the ordered range correlation without defining any sense of causality between those variables. Researchers selected a non-parametric alternative to Pearson's 
correlation studies and Spearman's rank-order non-parametric correlation coefficient [98]. The Tau-b test was applied, whose correlation is significant for a $p$-value at the 0.01 level -in 2 tails, statistically demonstrating an effect [99].

\section{Results}

After the exploratory factor analysis of the original 15 variables data set, researchers run an exploratory factor analysis (EFA). The authors preserved 12 variables from their EFA. Authors use SPSS 23 to obtain a KMO of 0.816 and Bartlett's test with a Chi-square of 1983.926 with 66 degrees of freedom and a significance level of 0.000 for the three factors CIE instrument. The authors achieved a $54.096 \%$ explained variance proportion (see Appendix B).

Additionally, the authors satisfactorily adapted the 12 variables analyzed data set for 12 variables to confirmatory factor analysis (CFA) with the use of the FACTOR software. The CFA obtained a KMO-Kaiser-Meyer-Olkin-equal to 0.82195 ( $>0.8)$ and Bartlett's test of sphericity with a Chi-Square 2905.2 with 66 degrees of freedom and a significance level of 0.000010 . Those results are significant and good enough to present the adequacy of the polychoric correlation matrix.

The Hull method for selecting the number of common factors, implemented with a goodness-of-fit index (GFI) with common part accounted for (CAF) and a method for dimensions' extraction (ULS) where the cumulative percentage of variance explained by the three factors of $71.811 \%$, a GFI $=0.997$, Bentler's simplicity index $(S)=0.99956$, Loading simplicity index $(\mathrm{LS})=0.81608$, Root Mean Square of Residuals $(\mathrm{RMSR})=0.0287$.

The authors reduced the CIE questionnaire according to its latent variables in three factors. Those factors weighted by the set of eigenvalues account for the entrepreneurial intention of the group of students analyzed. Researchers compared each of these three factors by gender, Intention Entrepreneurship (see Table 1), Entrepreneurship Self-Efficacy (see Table 2), Attitude towards Entrepreneurship (see Table 3), and Subjective Norm (see Table 4).

Table 1. Crosstab Scale IE and Gender.

\begin{tabular}{lllll}
\hline \multirow{2}{*}{ Scale_IE } & & Gender & \multicolumn{2}{c}{ Total } \\
\cline { 3 - 4 } & & Male & Female & \\
\hline \multirow{3}{*}{ High_IE } & Count & $140 \mathrm{a}$ & $87 \mathrm{a}$ & 227 \\
& Expected Count & 143.0 & 84.0 & 227.0 \\
& \% within Gender & $51.1 \%$ & $54.0 \%$ & $52.2 \%$ \\
Medium_IE & Count & $59 \mathrm{a}$ & $33 \mathrm{a}$ & 92 \\
& Expected Count & 57.9 & 34.1 & 92.0 \\
Low_IE & \% within Gender & $21.5 \%$ & $20.5 \%$ & $21.1 \%$ \\
& Count & $75 \mathrm{a}$ & $41 \mathrm{a}$ & 116 \\
& Expected Count & 73.1 & 42.9 & 116.0 \\
\multirow{2}{*}{ Total } & \% within Gender & $27.4 \%$ & $25.5 \%$ & $26.7 \%$ \\
& Count & 274 & 161 & 435 \\
& Expected Count & 274.0 & 161.0 & 435.0 \\
& \% within Gender & $100.0 \%$ & $100.0 \%$ & $100.0 \%$ \\
\hline
\end{tabular}

a. denotes a subset of Gender categories whose column proportions do not differ significantly from each other at the 0.05 level. 
Table 2. Crosstab Scale ESE and Gender.

\begin{tabular}{lllll}
\hline \multirow{2}{*}{ Scale_ESE } & & \multicolumn{2}{c}{ Gender } & \multirow{2}{*}{ Total } \\
\cline { 3 - 4 } & & Male & Female & \\
\hline \multirow{2}{*}{ High_ESE } & Count & $137 \mathrm{a}$ & $85 \mathrm{a}$ & 222 \\
& Expected Count & 139.8 & 82.2 & 222.0 \\
Medium_ESE & \% within Gender & $50.0 \%$ & $52.8 \%$ & $51.0 \%$ \\
& Count & $71 \mathrm{a}$ & $33 \mathrm{a}$ & 104 \\
& Expected Count & 65.5 & 38.5 & 104.0 \\
& \% within Gender & $25.9 \%$ & $20.5 \%$ & $23.9 \%$ \\
Low_ESE & Count & $66 \mathrm{a}$ & $43 \mathrm{a}$ & 109 \\
& Expected Count & 68.7 & 40.3 & 109.0 \\
\multirow{2}{*}{ Total } & \% within Gender & $24.1 \%$ & $26.7 \%$ & $25.1 \%$ \\
& Count & 274 & 161 & 435 \\
& Expected Count & 274.0 & 161.0 & 435.0 \\
& \% within Gender & $100.0 \%$ & $100.0 \%$ & $100.0 \%$ \\
\hline
\end{tabular}

a. denotes a subset of Gender categories whose column proportions do not differ significantly from each other at the 0.05 level.

Table 3. Crosstab Scale AtE and Gender.

\begin{tabular}{lllll}
\hline \multirow{2}{*}{ Scheme } & & Gender & \multirow{2}{*}{ Total } \\
\cline { 3 - 4 } & & Male & Female & \\
\hline \multirow{3}{*}{ High_AtE } & Count & $125 \mathrm{a}$ & $78 \mathrm{a}$ & 203 \\
& Expected Count & 127.9 & 75.1 & 203.0 \\
& \% within Gender & $45.6 \%$ & $48.4 \%$ & $46.7 \%$ \\
Low_AtE & Count & $99 \mathrm{a}$ & $42 \mathrm{~b}$ & 141 \\
& Expected Count & 88.8 & 52.2 & 141.0 \\
& \% within Gender & $36.1 \%$ & $26.1 \%$ & $32.4 \%$ \\
Medium_AtE & Count & $50 \mathrm{a}$ & $41 \mathrm{a}$ & 91 \\
& Expected Count & 57.3 & 33.7 & 91.0 \\
\multirow{2}{*}{ Total } & \% within Gender & $18.2 \%$ & $25.5 \%$ & $20.9 \%$ \\
& Count & 274 & 161 & 435 \\
& Expected Count & 274.0 & 161.0 & 435.0 \\
& \% within Gender & $100.0 \%$ & $100.0 \%$ & $100.0 \%$
\end{tabular}

a. denotes a subset of Gender categories whose column proportions do not differ significantly from each other at the 0.05 level. $\mathrm{b}$. Using the asymptotic standard error assuming the null hypothesis.

Table 4. Crosstab Scale SN and Gender.

\begin{tabular}{lllll}
\hline \multirow{2}{*}{ Scale_SN } & & Gender & \multirow{2}{*}{ Total } \\
\cline { 3 - 4 } & & Male & Female & \\
\hline \multirow{3}{*}{ High_SN } & Count & $105 \mathrm{a}$ & $76 \mathrm{a}$ & 181 \\
& Expected Count & 114.0 & 67.0 & 181.0 \\
& \% within Gender & $38.3 \%$ & $47.2 \%$ & $41.6 \%$ \\
Low_SN & Count & $100 \mathrm{a}$ & $46 \mathrm{a}$ & 146 \\
& Expected Count & 92.0 & 54.0 & 146.0 \\
\multirow{2}{*}{ Medium_SN } & \% within Gender & $36.5 \%$ & $28.6 \%$ & $33.6 \%$ \\
& Count & $69 \mathrm{a}$ & $39 \mathrm{a}$ & 108 \\
\multirow{2}{*}{ Total } & Expected Count & 68.0 & 40.0 & 108.0 \\
& \% within Gender & $25.2 \%$ & $24.2 \%$ & $24.8 \%$ \\
& Count & 274 & 161 & 435 \\
& Expected Count & 274.0 & 161.0 & 435.0 \\
& \% within Gender & $100.0 \%$ & $100.0 \%$ & $100.0 \%$ \\
\hline
\end{tabular}

a. denotes a subset of Gender categories whose column proportions do not differ significantly from each other at the 0.05 level.

Each subscript letter denotes a subset of gender categories whose column proportions do not differ significantly from each other at the 0.05 level. An asymptotic standardized error of 0.046 implies not assuming the null hypothesis. Approximate $\mathrm{T}-0.540$ using 
the asymptotic standard error implies assuming the null hypothesis. The approximate significance is 0.589 .

Each subscript letter denotes a subset of gender categories whose column proportions do not differ significantly from each other at the 0.05 level. An asymptotic standardized error of 0.045 implies not assuming the null hypothesis. Approximate $\mathrm{T}-0.921$ using the asymptotic standard error implies assuming the null hypothesis. The approximate significance is 0.357 .

Each subscript letter denotes a subset of gender categories whose column proportions do not differ significantly from each other at the 0.05 level. An asymptotic standardized error of 0.047 implies not assuming the null hypothesis. Approximate T 0.297 using the asymptotic standard error implies assuming the null hypothesis. The approximate significance is 0.766 .

Each subscript letter denotes a subset of gender categories whose column proportions do not differ significantly from each other at the 0.05 level. The asymptotic standardized error is 0.046 , therefore, not assuming the null hypothesis. Approximate $\mathrm{T}-1.338$ using the asymptotic standard error assuming the null hypothesis. The approximate significance is 0.181 .

\section{Discussion}

Entrepreneurial behavior, and more generally entrepreneurship, has long been a theoretical concern among economists and business scholars [100]. As Krueger et al. [18] argue, business intentions are one of the most important predictors of the new business behavior of individuals of both genders. The present research shows that there are no significant differences regarding gender entrepreneurial intention. Besides, there are no differences in the variables of self-efficacy, subjective norm, and entrepreneurial attitude, when measured by each gender. These findings reinforce some similar results in the literature on entrepreneurial intention [101-104].

Contrary to some literature findings, which have shown gender differences in entrepreneurial intentions for different countries and continents, this research presents nonsignificant differences. Studies have shown that EI in the US presents a positive orientation in men [105]. On the other hand, some studies in Asia and Africa have indicated that self-efficacy $[106,107]$ presents a greater female entrepreneurial intention than in males. Furthermore, this study presents research results that are in contrast with those obtained from the GEM study, which has shown that the self-efficacy dimension presents higher levels in the case of the female gender within the measurement of entrepreneurial intention [42,108], showing progress in sustainable development linked to gender equality (SDG 5).

All in all, the analyzed data set show a higher entrepreneurial intention. The sample presents over $50 \%$ of EI for both genders. Such a result makes it possible to conjecture that education for entrepreneurship is an element that positively affects the level of entrepreneurial intention, as shown in the literature $[5,109]$. This effect may be related to the sample type, a sample that researchers selected in a business school. Furthermore, entrepreneurship classes could be affecting the level of business student intentions $[41,57,58]$. Authors agree with Fayolle [44] that research on educational variables such as pedagogies and learning objectives and their effects on gender differences with EI measures could be a fertile place for future research, deepening the effects of quality education (SDG 4) that improves gender equality (SDG 5) and, in general, allows for the reduction of inequalities (SDG 10).

\section{Conclusions}

The article contributes in three aspects, first, guided by the literature, it improves understanding of gender and its effects on Intention Entrepreneurship (see Table 1), Entrepreneurship Self-Efficacy (see Table 2), Attitude towards Entrepreneurship (see Table 3), and Subjective Norm (see Table 4). In which, it was found that there is neither evidence for gender differences in any of three entrepreneurial intention factors IE, attitudes, subjective norms, and control of perceived behavior, in economics and administration students from 
a Latin American country. Second, a political point of view, since in Latin America due to the different sociocultural influences, the role of women in society continues to evolve in people's consciousness and where this study provides us with elements that put men on equal footing to the promotion and support of women in entrepreneurship. Finally, from a practical point of view, this study contributes to greater social sustainability, being able to be used as an argumentative basis for the creation of quality programs in entrepreneurial education (SDG 4) that achieves equal opportunities for men and women (SDG 5), eliminating gender differences in their entrepreneurship intention, and reinforcing equal access to opportunities generated by entrepreneurship in massive educational contexts that are oriented to socioeconomically emerging sectors (SDG 10).

In terms of limitations, the study shows a limited case and further research must be done to generalize researchers' findings. Additionally, this paper's results open further possibilities to raise questions about cultural factors that could explain differences between the case of this economics and business students and previous literature reports on gender IE differences in Latin American contexts and compare with other academic programs in different disciplines of knowledge and in various university contexts.

Supplementary Materials: The following are available online at https:/ /www.mdpi.com/article/10 .3390/su13094693/s1, Table S1: IE_UNAB_VL.xlsx.

Author Contributions: Conceptualization, N.C.-B. and G.S.-S.; methodology, A.V.-M. and J.F.E.-C.; software, A.V.-M.; validation, N.C.-B. and J.F.E.-C.; formal analysis, A.V.-M. and J.F.E.-C.; writingoriginal draft preparation, N.C.-B. and G.S.-S.; writing-review and editing, A.V.-M. and J.F.E.-C.; supervision, J.F.E.-C.; project administration, N.C.-B.; funding acquisition, G.S.-S. All authors have read and agreed to the published version of the manuscript.

Funding: The APC was partially funded by Universidad Católica de la Santísima Concepción.

Institutional Review Board Statement: The study was conducted according to the guidelines of the Declaration of Helsinki, but has not been submitted to an Institutional Review Board.

Informed Consent Statement: Informed consent was obtained from all subjects involved in the study.

Data Availability Statement: Data Availability with Supplementary materials, according MDPI Research Data Policies.

Conflicts of Interest: The authors declare no conflict of interest.

\section{Appendix A}

Table A1. Intention Entrepreunership Questionnaire.

\begin{tabular}{|c|c|c|}
\hline Spanish & English Translation & Variables \\
\hline $\begin{array}{l}\text { A. Crear una nueva empresa (ser } \\
\text { emprendedor) para Ud. Significaría ... }\end{array}$ & $\begin{array}{l}\text { A. To create a new company -being an } \\
\text { entrepreneur- would mean }\end{array}$ & \\
\hline Enfrentarme a nuevos retos. & Face new challenges & V01: Attitude_towards_Entrep_1 \\
\hline Crear empleo para otras personas. & Create employment for other people. & V02: Attitude_towards_Entrep_2 \\
\hline Ser creativo e innovar & Be creative and innovate & V03: Attitude_towards_Entrep_3 \\
\hline Tener altos ingresos económicos. & To earn a high economic income. & V04: Attitude_towards_Entrep_4 \\
\hline Asumir riesgos calculados. & Take calculated risks. & V05: Attitude_towards_Entrep_5 \\
\hline Ser mi propio jefe (independencia). & $\begin{array}{l}\text { Be my own boss (economic } \\
\text { independence). }\end{array}$ & V06: Attitude_towards_Entrep_6 \\
\hline $\begin{array}{l}\text { B. Por favor, indique hasta qué punto } \\
\text { sería Ud. capaz de realizar eficazmente } \\
\text { las siguientes tareas: }\end{array}$ & $\begin{array}{l}\text { B. Please indicate the extent to which you } \\
\text { would be able to effectively perform the } \\
\text { following tasks: }\end{array}$ & \\
\hline $\begin{array}{l}\text { Definir mi idea de negocio y la estrategia } \\
\text { de una nueva empresa. }\end{array}$ & $\begin{array}{l}\text { Define my business idea and the strategy } \\
\text { of a new company. }\end{array}$ & V07 Entrep_Self_Effic_1 \\
\hline $\begin{array}{l}\text { Mantener bajo control el proceso de } \\
\text { creación de una nueva empresa }\end{array}$ & $\begin{array}{l}\text { Keep the process of creating a new } \\
\text { company under control }\end{array}$ & V08 Entrep_Self_Effic_2 \\
\hline
\end{tabular}


Table A1. Cont.

\begin{tabular}{|c|c|c|}
\hline Spanish & English Translation & Variables \\
\hline $\begin{array}{l}\text { Negociar y mantener relaciones } \\
\text { favorables con potenciales inversores y } \\
\text { bancos. }\end{array}$ & $\begin{array}{l}\text { Negotiate and maintain favorable } \\
\text { relationships with potential investors and } \\
\text { banks. }\end{array}$ & V09 Entrep_Self_Effic_3 \\
\hline $\begin{array}{l}\text { Reconocer oportunidades en el mercado } \\
\text { para nuevos productos y/o servicios. }\end{array}$ & $\begin{array}{l}\text { Recognize opportunities in the market for } \\
\text { new products and/or services. }\end{array}$ & V10 Entrep_Self_Effic_4 \\
\hline $\begin{array}{l}\text { Relacionarme con personas clave para } \\
\text { obtener capital para crear una nueva } \\
\text { empresa. }\end{array}$ & $\begin{array}{l}\text { Connect with key people to obtain capital } \\
\text { to create a new company. }\end{array}$ & V11 Entrep_Self_Effic_5 \\
\hline $\begin{array}{l}\text { Crear y poner en funcionamiento una } \\
\text { nueva empresa. }\end{array}$ & Create and start a new company. & V12 Entrep_Self_Effic_6 \\
\hline $\begin{array}{l}\text { C. Por favor, piense ahora en sus } \\
\text { familiares y amigos más cercanos. ¿En } \\
\text { qué grado se mostrarían de acuerdo si } \\
\text { decide emprender y crear su propia } \\
\text { empresa? }\end{array}$ & $\begin{array}{l}\text { C. Please think about your closest family } \\
\text { and friends now. To what degree would } \\
\text { they agree if you decide to start and } \\
\text { create your own business? }\end{array}$ & \\
\hline Mi familia directa (padres y hermanos). & My direct family (parents and siblings). & V13 Subjective_Norm_1 \\
\hline La de mis amigos íntimos. & My close friends & V14 Subjective_Norm_2 \\
\hline La de mis compañeros o colegas. & My colleagues & V15 Subjective_Norm_3 \\
\hline
\end{tabular}

\section{Appendix B}

Table A2. Exploratory Factor Analysis.

\begin{tabular}{|c|c|c|c|c|}
\hline \multicolumn{5}{|l|}{ KMO and Bartlett's Test } \\
\hline \multicolumn{4}{|c|}{ Kaiser-Meyer-Olkin Measure of Sampling Adequacy } & 0.816 \\
\hline Bartlett's Test of Sphericity & $\begin{array}{l}\text { Approx. Chi-Square } \\
\text { df } \\
\text { Sig }\end{array}$ & & & $\begin{array}{l}1,983,926 \\
66 \\
0.000\end{array}$ \\
\hline \multicolumn{5}{|l|}{ Pattern Matrix a } \\
\hline & Factor 1 & Factor 2 & Factor 3 & \\
\hline Entrep_Self_Effic_2 & 0.798 & & & \\
\hline Entrep_Self_Effic_3 & 0.768 & & & \\
\hline Entrep_Self_Effic_6 & 0.735 & & & \\
\hline Entrep_Self_Effic_4 & 0.729 & & & \\
\hline Entrep_Self_Effic_5 & 0.692 & & & \\
\hline Entrep_Self_Effic_1 & 0.610 & & & \\
\hline Subjective_Norm_2 & & 1.022 & & \\
\hline Subjective_Norm_1 & & 0.644 & & \\
\hline Subjective_Norm_3 & & 0.561 & & \\
\hline Attitude_towards_Entrep_1 & & & 0.791 & \\
\hline Attitude_towards_Entrep_3 & & & 0.710 & \\
\hline Attitude_towards_Entrep_2 & & & 0.589 & \\
\hline Eigenvalues & 3.735 & 1.807 & 0.950 & \\
\hline$\%$ of Variance & 31.125 & 15.056 & 7.915 & \\
\hline Cumulative \% & 31.125 & 46.181 & 54.096 & \\
\hline
\end{tabular}

Factor Correlation Matrix ${ }^{\mathbf{b}}$

\begin{tabular}{llll}
\hline Factor & 1 & 2 & 3 \\
1 & 1000 & 0.171 & 0.379 \\
2 & 0.171 & 1000 & 0.351 \\
3 & 0.379 & 0.351 & 1.000
\end{tabular}

a. Extraction Method: Unweighted Least Squares. Rotation Method: Oblimin with Kaiser Normalization. Rotation converged in 4 iterations. ${ }^{\mathrm{b}}$. Extraction Method: Unweighted Least Squares. Rotation Method: Oblimin with Kaiser Normalization. 


\section{Appendix C}

Adequacy of The Polychoric Correlation Matrix.

Determinant of the matrix $=0.001130355385301$.

Bartlett's statistic $=2905.2(\mathrm{df}=66 ; P=0.000010)$.

Kaiser-Meyer-Olkin (KMO) test $=0.82195$ (good).

Rotated Loading Matrix (loadings lower than absolute 0.300 omitted).

Table A3. Confirmatory Factor Analysis.

\begin{tabular}{llll}
\hline Variable & F1 & F2 & F3 \\
\hline V01 & & & 0.825 \\
V02 & & & 0.738 \\
V03 & 0.665 & & 0.758 \\
V07 & 0.823 & & \\
V08 & 0.809 & & \\
V09 & 0.771 & & \\
V10 & 0.723 & & \\
V11 & 0.773 & 0.769 & \\
V12 & & 0.995 & \\
V13 & & 0.714 & 1.331 \\
V14 & 2.344 & 11.09 \\
V15 & 4.942 & 19.54 & 71.81 \\
Eigenvalues & 41.19 & 60.72 & \\
\% of Variance & 41.19 & & F3 \\
Cumulative \% & F2 & \\
\hline Inter-Factors Correlation Matrix & & \\
\hline Factor & F1 & 1.000 & 1.000 \\
\hline 1 & 1.000 & 0.430 & \\
2 & 0.226 & & \\
3 & 0.420 & & \\
\hline
\end{tabular}

\section{References}

1. Collins, L.A.; Smith, A.J.; Hannon, P.D. Applying a Synergistic Learning Approach in Entrepreneurship Education. Manag. Learn. 2006, 37, 335-354. [CrossRef]

2. Gibb, A. In Pursuit of a New Entrepreneurial Paradigm for Learning: Creative Destruction, New Values, New Ways of Doing Things and New Combination of Knowledge. Int. J. Manag. Rev. 2002, 4, 233-269. [CrossRef]

3. Krueger, N.F. What lies beneath? The experiential essence of entrepreneurial thinking. Entrep. Theory Pract. 2007, 31, 123-138. [CrossRef]

4. Mitchell, R.K.; Busenitz, L.; Bird, B.; Gaglio, C.; McMullen, J.; Morse, E.; Smith, J. The central question in entrepreneurial cognition research. Entrep. Theory Pract. 2007, 31, 1-27. [CrossRef]

5. Pittaway, L.; Cope, J. Entrepreneurship Education A Systematic Review of the Evidence. Int. Small Bus. J. 2007, 25, 479-510. [CrossRef]

6. Global Entrepreneurship Monitor. Global Report 2017/2018; Global Entrepreneurship Research Association and London Business School: London, UK, 2018.

7. Contreras-Barraza, N.; Espinosa-Cristia, J.F.; Salazar-Sepulveda, G.; Vega-Muñoz, A.; Ariza-Montes, A. A Scientometric Systematic Review of Entrepreneurial Wellbeing Knowledge Production. Front. Psychol. Rev. 2021, 12, 641465. [CrossRef]

8. Soria-Barreto, K.; Zuniga-Jara, S.; Ruiz-Campo, S. Educación e Intención Emprendedora en Estudiantes Universitarios: Un Caso de Estudio. Form. Univ. 2016, 9, 25-34. [CrossRef]

9. Lortie, J.; Castogiovanni, G. The theory of planned behavior in entrepreneurship research: What we know and future directions. Int. Entrep. Manag. J. 2015, 11, 935-957. [CrossRef]

10. Ajzen, I. Theory of planned behavior. Organ. Behav. Hum. Decis. Process. 1991, 50, 179-211. [CrossRef]

11. Ajzen, I. The theory of planned behaviour: Reactions and reflections. Psychol. Health 2011, 26, 1113-1127. [CrossRef]

12. Furdui, A.; Lupu-Dima, L.; Edelhauser, E. Implications of Entrepreneurial Intentions of Romanian Secondary Education Students, over the Romanian Business Market Development. Processes 2021, 9, 665. [CrossRef]

13. Peng, H.; Li, B.; Zhou, C.; Sadowski, B.M. How Does the Appeal of Environmental Values Influence Sustainable Entrepreneurial Intention? Int. J. Environ. Res. Public Health 2021, 18, 1070. [CrossRef] [PubMed]

14. Ruzzier, M.; Douglas, E.J.; Ruzzier, M.K.; Hojnik, J. International Entrepreneurial Orientation and the Intention to Internationalize. Sustainability 2020, 12, 5647. [CrossRef]

15. Müller, J.; Acevedo-Duque, Á.; Müller, S.; Kalia, P.; Mehmood, K. Predictive Sustainability Model Based on the Theory of Planned Behavior Incorporating Ecological Conscience and Moral Obligation. Sustainability 2021, 13, 4248. [CrossRef] 
16. Armitage, C.; Conner, M. Efficacy of the Theory of Planned Behaviour: A Meta-Analytic Review. Br. J. Soc. Psychol. 2010, 40, 471-499. [CrossRef]

17. Autio, E.; Keeley, R.H.; Klofsten, M.; Parker, G.G.C.; Hay, M. Entrepreneurial intent among students in Scandinavia and in the USA. Enterp. Innov. Manag. Stud. 2001, 2, 145-160. [CrossRef]

18. Krueger, N.F.; Reilly, M.D.; Carsrud, A.L. Competing models of entrepreneurial intentions. J. Bus. Ventur. 2000, 15, 411-432. [CrossRef]

19. Liñán, F.; Fayolle, A. A systematic literature review on entrepreneurial intentions: Citation, thematic analyses, and research agenda. Int. Entrep. Manag. J. 2015, 11, 907-933. [CrossRef]

20. Moriano, J.A.; Gorgievski, M.; Laguna, M.; Stephan, U.; Zarafshani, K. A cross-cultural approach to understanding entrepreneurial intention. J. Career Dev. 2012, 39, 162-185. [CrossRef]

21. Thompson, E.R. Individual Entrepreneurial Intent: Construct Clarification and Development of an Internationally Reliable Metric. Entrep. Theory Pract. 2009, 33, 669-694. [CrossRef]

22. Ruiz-Navarro, J.; Camelo, C.; Coduras, A. Mujer y desafío emprendedor en España. Características y determinantes. Econ. Ind. 2012, 383, 13-22.

23. Gupta, V.K.; Turban, D.B.; Arzu Wasti, S.; Sikdar, A. The Role of Gender Stereotypes in Perceptions of Entrepreneurs and Intentions to Become an Entrepreneur. Entrep. Theory Pract. 2009, 33, 397-417. [CrossRef]

24. Reynolds, P.; Bosma, N.; Autio, E.; Hunt, S.; De Bono, N.; Servais, I.; Lopez-Garcia, P.; Chin, N. Global Entrepreneurship Monitor: Data Collection Design and Implementation 1998-2003. Small Bus. Econ. 2005, 24, 205-231. [CrossRef]

25. Gatewood, E.; Carter, N.M.; Brush, C.G.; Greene, P.G.; Hart, M.M. Women Entrepreneurs, Their Ventures, and the Venture Capital Industry: An Annotated Bibliography; Entrepreneurship and Small Business Research Institute: Stockholm, Sweden, 2003.

26. Brush, C.G. Women-owned businesses: Obstacles and opportunities. J. Dev. Entrep. 1997, 2, 1-24.

27. García-Aramayo, A.; Contreras-Espinosa, R.S. Mujeres empresarias en internet. 3C Empresa 2014, 3, 147-159.

28. Ortiz-García, P. El discurso sobre el emprendimiento de la mujer desde una perspectiva de género. Vivat Acad. 2017, 140, 115-129. [CrossRef]

29. Tsui, M. Gender and mathematics achievement in China and the United States. Gend. Issues 2007, 24, 1-11. [CrossRef]

30. Wilson, F.; Kickul, J.; Marlino, D. Gender, entrepreneurial self-efficacy, and entrepreneurial career intentions: Implications for entrepreneurship education. Entrep. Theory Pract. 2007, 31, 387-406. [CrossRef]

31. Sánchez, J.; Lanero, A.; Yurrebaso, A. Variables determinantes de la intención emprendedora en el contexto universitario. Rev. Psicol. Soc. Apli. 2005, 15, 37-60.

32. Harrison, G.W.; List, J.A. Field experiments. J. Econ. Lit. 2004, 42, 1009-1055. [CrossRef]

33. Rueda, S.; Moriano, J.A.; Liñán, F. Validating a Theory of Planned Behavior Questionnaire to Measure Entrepreneurial Intentions; Fayolle, A., Kyrö, P., Liñán, F., Eds.; Developing, Shaping and Growing Entrepreneurship; Edward Elgar: London, UK, 2015 ; pp. 60-78.

34. Muñoz, M.; Blanco, C. Taxonomy of Chilean Universities. Calid. Educ. 2013, 181-213. [CrossRef]

35. Rodríguez-Ponce, E.; Gaete-Feres, H.; Pedraja-Rejas, L.; Araneda-Guirriman, C. An approach toward a classification of Chilean higher education institutions. Ingeniare Rev. Chil. Ing. 2015, 23, 328-340. [CrossRef]

36. Fernández-Darraz, E. Public policy, market and institutional diversity: The complexity of classifying higher education institutions. The Chilean case. Innovar 2018, 28, 147-158. [CrossRef]

37. National Education Council-Chile. Undergraduate (2005-2020) and Graduate (2005-2019) Database by Program. The File Contains Information on: Enrollment, Vacancies, Fees and University Selection Test (PSU). Available online: https://www.cned. cl/sites/default/files/baseindices_2005-2020.xlsx (accessed on 18 April 2021).

38. Rodriguez-Garces, C.; Castillo-Riquelme, V. Professional stock, educational efficiency and segmentation: Process analysis of professional training in Chile. Civilizar 2015, 15, 183-196. Available online: http:/ / ref.scielo.org/5vfs76 (accessed on 18 April 2021). [CrossRef]

39. Elfving, J. Contextualizing Entrepreneurial Intentions: A Multiple Case Study on Entrepreneurial Cognition and Perception; Abo Akademi University Press: Turku, Finland, 2008.

40. Shapero, A.; Sokol, L. The social dimension of entrepreneurship. In Encyclopedia of Entrepreneurship; Kent, C.A., Sexton, D.L., Vesper, K.H., Eds.; Prentice-Hall Englewood Cliffs: New Jersey, NJ, USA, 1982; pp. 72-90.

41. Krueger, N.; Carsrud, A.L. Entrepreneurial intentions: Applying the theory of planned behaviour. Entrep. Reg. Dev. 1993, 5, 315-330. [CrossRef]

42. Veciana, J.M. La Creación de Empresas: Un Enfoque Gerencial; La Caixa: Barcelona, Spain, 2005.

43. Krueger, N.F.; Brazeal, D. Entrepreneurial Potential and Potential Entrepreneurs. Entrep. Theory Pract. 1994, 18, 91-104. [CrossRef]

44. Fayolle, A. Personal Views on the Future of Entrepreneurship Education. Entrep. Reg. Dev. 2013, 25, 692-701. [CrossRef]

45. Ratten, V.; Usmanij, P. Entrepreneurship education: Time for a change in research direction? Int. J. Manag. Educ. 2020, 19, 100367. [CrossRef]

46. Sirelkhatim, F.; Gangi, Y. Entrepreneurship education: A systematic literature review of curricula contents and teaching methods. Cogent Bus. Manag. 2015, 2, 1052034. [CrossRef]

47. Haase, H.; Lautenschläger, A. The Teachability Dilemma of Entrepreneurship. Int. Entrep. Manag. J. 2011, 7, 145-162. [CrossRef]

48. McMullan, W.E.; Long, W.A. Entrepreneurship Education in the Nineties. J. Bus. Ventur. 1987, 2, 261-275. [CrossRef] 
49. Neck, H.M.; Greene, P.G. Entrepreneurship education: Known worlds and new frontiers. J. Small Bus. Manag. 2011, 49, 55-70. [CrossRef]

50. Maritz, A.; Brown, C. Illuminating the black box of entrepreneurship education programs. Educ. Train. 2013, 55. [CrossRef]

51. Kyrö, P. A theoretical framework for teaching and learning entrepreneurship. Int. J. Bus. Global. 2008, 2, 39-55. [CrossRef]

52. Fayolle, A.; Benoît, G. From Craft to Science: Teaching Models and Learning Processes in Entrepreneurship Education. J. Eur. Ind. Train. 2008, 32, 569-593. [CrossRef]

53. Kember, D. A Reconceptualisation of the Research into University Academics Conceptions of Teaching. Learn Instr. 1997, 7, 255-275. [CrossRef]

54. Norton, L.; Richardson, J.; Hartley, J.; Newstead, S.; Mayes, J. Teachers' Beliefs and Intentions Concerning Teaching in Higher Education. High. Educ. 2005, 50, 537-571. [CrossRef]

55. Béchard, J.P.; Grégoire, D. Entrepreneurship Education Research Revisited: The Case of Higher Education. Acad. Manag. Learn. Innov. 2005, 4, 22-43. [CrossRef]

56. Matlay, H.; Hannon, P.D. Teaching pigeons to dance: Sense and meaning in entrepreneurship education. Educ. Train. 2006, 48, 296-308. [CrossRef]

57. Von Graevenitz, G.; Weber, R.; Harhoff, D. The Effects of Entrepreneurship Education. J. Econ. Behav. Organ. 2010, 76, 90-112. [CrossRef]

58. Fayolle, A.; Liñán, F. The Future of Research on Entrepreneurial Intentions. J. Bus. Res. 2013, 67, 663-666. [CrossRef]

59. Akter, M.; Rahman, M.; Radicic, D. Women entrepreneurship in international trade: Bridging the gap by bringing feminist theories into entrepreneurship and internationalization theories. Sustainability 2019, 11, 6230. [CrossRef]

60. De Bruin, A.; Brush, C.G.; Welter, F. Introduction to the special issue: Towards building cumulative knowledge on women's entrepreneurship. Entrep. Theory Pract. 2006, 30, 585-593. [CrossRef]

61. Thebaud, S. Gender and Entrepreneurship as a Career Choice: Do Self-Assessments of Ability Matter? Soc. Psychol. Quart. 2010, 73, 288-304. [CrossRef]

62. Ahl, H. Why Research on Women Entrepreneurs Needs New Directions. Entrep. Theory Pract. 2006, 30, 595-621. [CrossRef]

63. Lewis, P. The Quest for Invisibility: Female Entrepreneurs and the Masculine Norm of Entrepreneurship. Gend. Work. Organ. 2006, 13, 453-469. [CrossRef]

64. Langowitz, N.; Minniti, M. The Entrepreneurial Propensity of Women. Entrep. Theory Pract. 2007, 31, 341-364. [CrossRef]

65. Arenius, P.; Minniti, M. Perceptual variables and nascent entrepreneurship. Small Bus. Econ. 2005, 24, 233-247. [CrossRef]

66. Koellinger, P.; Minniti, M.; Schade, C. Gender Differences in Entrepreneurial Propensity. Oxf. Bull. Econ. Stat. 2011, 75, 213-234. [CrossRef]

67. Ljunggren, E.; Kolvereid, L. New Business Formation: Does Gender Make a Difference? Women Manag. Rev. 1996, 11, 3-12. [CrossRef]

68. Sahinidis, A.; Giovanis, A.; Sdrolias, L. The role of gender on entrepreneurial intention among students: An empirical test of the theory of planned behavior in a greek university. Int. J. Integr. Inf. Manag. 2012, 1, 61-79. [CrossRef]

69. Van Ewijk, A.R.; Belghiti-Mahut, S. Context, gener and entrepreneurial education changes the equation. Int. J. Gend. Entrep. 2019, 11, 75-98. [CrossRef]

70. Ferri, L.; Ginesti, G.; Spanò, R.; Zampella, A. Exploring the Entrepreneurial Intention of Female Students in Italy. J. Open Innov. Technol. Mark. Complex 2018, 4, 27. [CrossRef]

71. Ahl, H. The construction of the female entrepreneur as the other. In Casting the Other: The Production and Maintenance of Inequalities in Work Organizations; Czarniawska, B., Höpfl, H., Eds.; Routledge: London, UK, 2002; pp. 52-67.

72. Pandit, D.; Joshi, M.P.; Tiwari, S.R. Examining Entrepreneurial Intention in Higher Education: An Exploratoy Study of College Students in India. J. Entrep. 2018, 27, 25-46. [CrossRef]

73. Azis, M.; Maulana Haeruddin, M.I.; Azis, F. Entreprenuership Education and Career Intention: The Perks of being a Woman Student. J. Entrep. Educ. 2018, 21, 1-10.

74. Naranjo, C. Gender Inequalities in Women's Entrepreneurship and Business. Rev. Trab. Soc. 2019, 3-12. Available online: http:/ / redae.uc.cl/index.php/RTS/article/view/2574 (accessed on 18 April 2021).

75. Chen, C.C.; Greene, P.G.; Crick, A. Does entrepreneurial self-efficacy distinguish entrepreneurs from managers? J. Bus. Ventur. 1998, 13, 295-316. [CrossRef]

76. Chowdhury, S.; Endres, M. Gender Difference and the Formation of Entrepreneurial Self-Efficacy; 2005. University of Illinois at Urbana-Champaign's Academy for Entrepreneurial Leadership Historical Research Reference in Entrepreneurship. Available online: http:/ / citeseerx.ist.psu.edu/viewdoc/summary;jsessionid=1F647A5DE6738C98DD24BE2506950893?doi=10.1.1.540.3341 (accessed on 18 April 2021).

77. Díaz-García, M.C.; Jiménez-Moreno, J. Entrepreneurial intention: The role of gender. Int. Entrep. Manag. J. 2010, 6, 261-283. [CrossRef]

78. Yordanova, D.; Tarrazon, M.A. Gender differences in entrepreneurial intentions: Evidence from Bulgaria. J. Dev. Entrep. 2010, 15, 245-261. [CrossRef]

79. Pincay-Gonzalez, J.B.; Peñarreta-Barrera, E.E. Análisis de la Intención Emprendedora en Jóvenes y Determinantes del Entorno Económico y Social para la Creación de Emprendimientos Exitosos en Guayaquil-Ecuador al año 2018. Bachelor's Thesis, Universidad de Guayaquil, Guayaquil, Ecuador, 2018. 
80. Tarapuez-Chamorro, E.; Parra-Hernández, R.; Gil-Giraldo, A. Social Norms and Entrepreneurial Intention in University Researchers in Colombia. Cuad. Adm. 2020, 36, 118-131.

81. Laguía, A.; Moriano, J.A.; Molero, F.; Gámez, J.A. Validación del Cuestionario de Intención Emprendedora en una muestra de estudiantes universitarios de Colombia. Univ. Psychol. 2017, 16, 1-14. [CrossRef]

82. Gálvez-Albarracín, E.J.; Guauña-Aguilar, R.A.; Pérez-Uribe, R.I. Impacto de la norma social subjetiva en la intención de emprendimiento sostenible: Un caso de estudio con estudiantes colombianos. Rev. Esc. Adm. Neg. 2018, 57-74. [CrossRef]

83. Restrepo, J.; Gálvez-Albarracín, E.J.; Guauña-Aguilar, R.A. Self-Efficacy and Entrepreneurial Intention: Case Study in an Intermediate City of Colombia. Int. J. Bus. Res. 2018, 18, 67-80. [CrossRef]

84. Siles-Nates, M.M. Análisis de los Factores de Intención Emprendedora, Propuesta de Modelo; Postgrado. Universidad Peruana Unión: Lima, Perú, 2020. Available online: http:/ / repositorio.upeu.edu.pe/handle/UPEU/3255 (accessed on 18 April 2021).

85. Galleguillos-Cortés, C.; Escobar-Burgos, B.; Hurtado-Cailly, R. Predictores de la Intención Emprendedora en Alumnos de Pregrado: Un Modelo Basado en Ecuaciones Estructurales. Form. Univ. 2019, 12, 83-94. [CrossRef]

86. Escobar-Quinteros, M.M. La Inteligencia Emocional y su Influencia en la Intención de Emprendimiento en los Estudiantes de la Facultad de Ciencias Empresariales de la Universidad Privada de Tacna, Periodo 2018. Bachelor's Thesis, Universidad Privada de Tacna, Tacna, Peru, 2019. Available online: http:/ /repositorio.upt.edu.pe/handle/UPT/835 (accessed on 18 April 2021).

87. Espinoza-Alcívar, E.I.; Jimber-Del-Río, J.A.; Casas-del-Rosal, J.C.; Ceular-Villamandos, N. Análisis de la intención emprendedora en estudiantes universitarios: Validación de la teoría de acción planificada. Rev. Cient. Ecocienc. 2019, 6, 1-17. [CrossRef]

88. Cortez, P.; Filho, N. Instrumentos de Evaluación de Intención Emprendedora: Una Revisión de Literatura. Cuad. Lat. Adm. 2020, 16. [CrossRef]

89. Gálvez-Albarracín, É.J.; Guauña-Aguilar, R.A.; Ravina-Ripoll, R. Actitud e intención emprendedora en estudiantes de administración de empresas y de contaduría pública. Rev. Univ. Empresa 2020, 22, 79-105. [CrossRef]

90. Lloret-Segura, S.; Ferreres-Traver, A.; Hernández-Baeza, A.; Tomás-Marco, I. Exploratory Item Factor Analysis: A practical guide revised and up-dated. An. Psicol. 2014, 30, 1151-1169. [CrossRef]

91. Ferrando, P.J.; Lorenzo-Seva, U. Program FACTOR at 10: Origins, development and future directions. Psicothema 2017, 29 , $236-241$. [CrossRef]

92. Lorenzo-Seva, U.; Timmerman, M.E.; Kiers, H.A.L. The Hull method for selecting the number of common factors. Multivar. Behav. Res. 2011, 46, 340-364. [CrossRef] [PubMed]

93. Bentler, P.M. Factor simplicity index and transformations. Psychometrika 1977, 59, 567-579. [CrossRef]

94. Lorenzo-Seva, U. A factor simplicity index. Psychometrika 2003, 68, 49-60. [CrossRef]

95. Harman, H.H. Modern Factor Analysis, 2nd ed.; University of Chicago Press: Chicago, IL, USA, 1962.

96. Kelley, T.L. Essential Traits of Mental Life. Harv. Stud. Educ. 1935, $26,146$.

97. Véliz-Capuñay, C. Analisis Multivariante: Métodos Estadísticos Multivariantes para la Investigación, 1st ed.; Cengage Learning: Cuidad Autónoma de Buenos Aires, Argentina, 2016; p. 208.

98. Hernández-Sampieri, R.; Fernández-Collado, C.; Baptista-Lucio, P. Metodología de la Investigación, 6th ed.; McGraw-Hill: México D.F, Mexico, 2014.

99. Romero-Suárez, N. La revolución en la toma de decisiones estadísticas: El p-valor. Telos 2012, 14, 439-446.

100. Sullivan, D.; Meek, W. Gender and entrepreneurship: A review and process model. J. Manag. Psychol. 2012, $27,428-458$. [CrossRef]

101. BarNir, A.; Watson, W.E.; Hutchins, H.M. Mediation and Moderated Mediation in the Relationship among Role Models, Self-Efficacy, Entrepreneurial Career Intention, and Gender. J. Appl. Soc. Psychol. 2001, 41, 270-297. [CrossRef]

102. Carr, J.C.; Sequeira, J.M. Prior Family Business Exposure as Intergenerational Influence and Entrepreneurial Intent: A Theory of Planned Behavior Approach. J. Bus. Res. 2007, 60, 1090-1098. [CrossRef]

103. Fernandez, J.; Linan, F.; Santos, F.J. Cognitive Aspects of Potential Entrepreneurs in Southern and Northern Europe: An Analysis Using Gem-Data. Rev. Econ. Mund. 2009, 23, 151-178.

104. Zellweger, T.; Sieger, P.; Halter, F. Should I Stay or Should I Go? Career Choice Intentions of Students with Family Business Background. J. Bus. Vent. 2011, 26, 521-536. [CrossRef]

105. Özarallı, N.; Rivenburgh, N. Entrepreneurial intention: Antecedents to entrepreneurial behavior in the U.S.A. and Turkey. J. Glob. Entrep. Res. 2016, 6, 1-32. [CrossRef]

106. Ephrem, A.N.; Namatovu, R.; Basalirwa, E.M. Perceived social norms, psychological capital and entrepreneurial intention among undergraduate students in Bukavu. Educ. Train. 2013, 61,963-983. [CrossRef]

107. Botha, M.; Bignotti, A. Exploring moderators in the relationship between cognitive adaptability and entrepreneurial intention: Findings from South Africa. Int. Entrep. Manag. J. 2017, 13, 1069-1095. [CrossRef]

108. Wannamakok, W.; Chang, Y.Y. Understanding nascent women entrepreneurs: An exploratory investigation into their entrepreneurial intentions. Gend. Manag. Int. J. 2020, 35, 553-566. [CrossRef]

109. Martin, B.C.; Mcnally, J.J.; Kay, M.J. Examining the formation of human capital in entrepreneurship: A meta-analysis of entrepreneurship education outcomes. J. Bus. Ventur. 2013, 28, 211-224. [CrossRef] 